
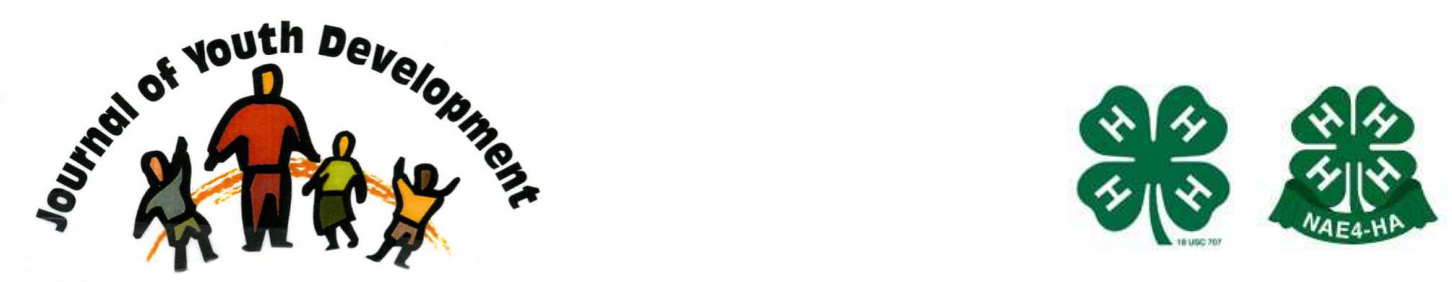

Bridging Research \& Practice

\title{
Positive Youth Development: A Resiliency-Based Afterschool Program Case Study
}

\author{
Lindsey Brown \\ Recreation, Parks \& Leisure Studies Dept. \\ SUNY Cortland \\ Cortland, NY \\ brown.lindseyj@gmail.com
}

Eddie Hill

Human Movement Sciences Dept.

Park, Recreation \& Tourism Studies Program

Old Dominion University

Norfolk, VA

ehill@odu.edu

Amy Shellman

Recreation, Parks \& Leisure Studies Dept.

SUNY Cortland

Cortland, NY

amy.shellman@cortland.edu

\section{Edwin Gómez}

Human Movement Sciences Dept.

Park, Recreation \& Tourism Studies Program

Old Dominion University

Norfolk, VA

egomez@odu.edu 


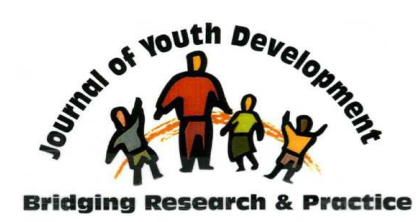

Volume 7, Number 4, Winter 2012
JOURNAL OF YOUTH DEVELOPMENT

bridging research and practice

\title{
Positive Youth Development: A Resiliency-Based Afterschool Program Case Study
}

\author{
Lindsey Brown and Amy Shellman \\ SUNY Cortland
}

Eddie Hill and Edwin Gómez

Old Dominion University

\begin{abstract}
This study examined the impact of an afterschool program on resilience in youth at an elementary school in Central NY. The goals of the program were to: (a) increase resiliency among participants, and (b) reduce the occurrence of aggressive behaviors (i.e., bullying) in $5^{\text {th }}$ and $6^{\text {th }}$ graders. Of the 79 students who completed the survey, 19 participants were able to be matched with pre- and posttests. In the study, 13 as participants in the afterschool program, and six as nonparticipants. Results of paired samples $t$-tests indicated that those who participated in the afterschool program showed a significant increase $(p=0.05)$ in resiliency scores. The program also had a positive impact on decreasing discipline-related referrals.
\end{abstract}

\section{Introduction}

Traditionally, youth development professionals have focused on the shortcomings of children. More recently, the youth development movement has taken a more strengths-based approach to achieve positive developmental outcomes. The strengths-based approach is a constructivist technique that deemphasizes pathology and focuses on interventions that build on individuals' strengths (Cheon, 2008). Particular attention is given to values, youth potential, school and community, self-determination and resiliency (Choen, 2008; Hill, Brown, \& Cosnett, 2011). This last construct, resiliency, is the focus of this study, and will be elaborated upon later in terms of a formal and operational definition.

A growing issue within elementary schools nationwide is aggressive behaviors, or bullying, within youth, potentially leading towards peer victimization, which may be alleviated by promoting resiliency among youth. For the purpose of this paper, the more common occurrences of victimization, such as disrupted behavior, are addressed, as opposed to the 
isolated incidents of highly publicized school tragedies (e.g., shootings and other lethal hostilities). Bullying is defined as hostile behavior that is intentionally directed towards another individual, where there is an imbalance of power, and it is usually repetitive (Cummings, 1999). Thus, the purpose of this research is to explore the perceived effects of a resiliency-based afterschool recreation intervention on levels of resiliency in youth and instances of aggressive behaviors.

\section{Positive Youth Development}

As was earlier suggested, in both social science research and pop culture, there has traditionally been a strong focus on what is "wrong" with people rather than what is "right" with people (Hurtes \& Allen, 2001), and until recently, scant attention has been paid to the strengths-based positive youth development perspective in preventing the onset of troubles with adolescents. The strengths-based approach deemphasizes pathology and builds interventions on the strengths of the individuals (Cheon, 2008).

An alternate perspective to negative, dysfunctional beliefs about youth development comes from positive psychology, a sub-discipline of psychology, defined as the "scientific study of human strength, resilience, and optimal human functioning," (Kelley, 2003, p. 49). Rather than focusing on treating youthful dysfunction, positive psychology facilitates well-being and resiliency in youth and promotes pro-social behavior (Kelley, 2003). Commonly, it is assumed that juvenile offenders are in some way, defective; lacking an essential quality (i.e., impulse control, self-esteem, cognitive functions, assertiveness, and social skills). Kelley wrote that atrisk youth would benefit if they were supplied with ways to prevent or control dysfunctional tendencies through programs that addressed these characteristics.

\section{Benefits of Afterschool Programming}

Much of the research indicates that between the time children arrive home from school and the time parents arrive home from work, there is an increased level of adolescent delinquent behavior due to a lack in supervision (Gottfredson, Cross \& Soule, 2007). In New York alone, approximately 931,686 children (27\%) take care of themselves afterschool and only 15\% (of K12 students) are able to participate in afterschool programs; furthermore, of those who cannot participate, 36\% would, if a program were available to them (Afterschool Alliance, 2004).

Borden, et al., (2005) identified four major categories regarding intrinsic and extrinsic reasons for why youths felt they should participate in out-of-school programs:

a) afterschool programs help them stay off the streets,

b) youths feel they have the ability to learn new things in afterschool programs,

c) programs help them avoid boredom, and

d) youth enjoy activities that are fun.

Students specifically mentioned that they liked the feeling of demonstrating they can be successful, that they had fun, and that they were given a chance to escape the confines of their home; in both a physical and philosophical sense. Borden and colleagues also identified four major constraints infringing upon youth's ability to participate in an activity:
a) lack of time,
b) other interests,
c) adverse impressions of the youth center, and
d) parental restrictions preventing participation. 
Five key recommendations were devised for designing youth programs in order to increase participation levels (Borden, et al., 2005):

a) define the participants that will be engaging in the program,

b) create programs that offer children the ability to develop essential life skills,

c) allow room for parents to be involved,

d) incorporate best practices, and

e) continuously evaluate the program.

These steps are aligned with the National Recreation and Park Association's Benefits-Based Programming (BBP) (Allen \& Cooper, 2003).

\section{Aggressive Behavior}

Graham and Bellmore (2007) noted that some occurrences of aggressive behaviors, or bullying, stem from an instance where an aggressive child misinterprets the actions of another child, thus becoming outwardly hostile towards that child. Different types of bullying have been identified including: direct bullying, which involves threats, teasing and taunts; verbal bullying, involving similar actions and including name calling, spreading rumors and excluding individuals; physical bullying, which includes destruction of property, hitting and physical altercations; and sexual harassment, which demeans a person based on their gender or sexual orientation (Beaty \& Alexeyev, 2008). Afterschool programs utilizing a positive youth development approach alleviate some of these aggressive behaviors. Add connection to Benefits of After School Programming.

Roffman, Pagano, and Hirsch (2001) conducted a study that explored the effects of an after school program on youth participating in the Boys and Girls Club of America. Roffman, et al. found that, on average, the boys in their sample had significantly higher rates of "getting into trouble" than the girls, and indicated that low income minority males may express socioemotional problems through externalized negative behaviors. In addition, the girls reported self-esteem levels relatively higher than the boys, and these reported levels did not decline with age. Both genders were asked to rate the extent to which staff influenced their decision to participate in the program. Girls rated the staff as a reason for participation a bit higher than the boys, suggesting that girls may create stronger relationships easier than boys with older role model figures.

Positive youth development encompasses a strength based conception of adolescence (Lerner, Lerner, Almerigi, \& Theokas, 2005). Some youth development specialists (Gambone, Klern, \& Connell, 2002; Leffert, et al., 1998; Witt, 2002) have indicated that, in addition to academic competence, youth need opportunities for appropriate physical development, and for emotional, civic, and social competence. Kelley (2003) stated that high rates of boredom, alienation, and disconnection from meaningful challenges are signs of a deficiency in positive youth development. This negative youth development could cause problem behavior such as drug use, premature sexual involvement, and minor delinquency.

\section{Resiliency}

Resiliency has been defined as the ability to bounce back, to withstand hardship and repair one's self (Wolin \& Wolin, 1993). The concept of resiliency is more than responding to difficult situations; it is the realization of cognitive capabilities, self-regulating behaviors and building of social support networks (Brennan, 2008). Brennan suggested that there are two types of resiliency: individual and community, and stated that through partnerships between youths and adults, young people can establish proper coping skills and adults can learn new and innovative ways to approach situations. 
Some research suggests that resiliency is innate; however, it is imperative for some children to be exposed to "protective factors" that can help combat "risk factors" thereby assisting children in fostering their own resiliency (Allen, et al., 1998; Benard, 2004; Hurtes, Allen, Stevens, \& Lee, 2000). Protective factors consist of individual or environmental characteristics that promote resiliency, such as having a positive youth mentor/coach, or a neighborhood with a healthy sense of community. Risk factors include increased levels of stress, and inconsistent parenting (Benard, 2004; Ellis, Braff, \& Hutchinson, 2001). According to Ellis and colleagues, leisure professionals promote youth development by designing programs that promote protective factors and hence, resiliency.

In Wolin and Wolin's (1993) conceptualization of resiliency, they identify seven constructs that comprise resiliency: Insight, the ability to understand verbal, body, and situational cues and modify behavior accordingly; Independence, the ability to separate one's self from risk factors or negative consequences; Relationship, the ability to form and maintain healthy relationships; Initiative, the ability to take charge and be self-determined; Creativity, the ability to generate healthy options and/or alternatives that will help to cope with hardships. Humor, is the ability to play and stay light-hearted; and Morality (or values orientation), the ability to recognize one's values or outcomes and see long-term to support a healthy life.

\section{Benefits-Based Programming}

The goal of the Benefits-Based Movement is to alter the perception of recreation as an optional leisure activity, to a vital, human service, with preventive, developmental, and rehabilitative aspects (Allen, et al., 1998). These benefits correspond highly with the risk and protective factors inherent in the resiliency literature. As part of the Benefits-Based Movement, the Benefits-Based Programming (BBP) model includes four steps:

a) outcome oriented program goals should be identified and meaningful to the agency, the participants, and other stakeholders to ensure that the program goals and objectives coincide with the users' and stakeholders' expectations of program outcomes;

b) program components should be intentionally structured to address the stated goals (i.e., the programmers must discover the theory (e.g., resiliency) on which successful programs are based, and they must then find supporting literature to make informed changes to a program to suit the needs of the target population);

c) progress toward desired goals must be assessed(e.g., formative and summative via program evaluation); and

d) an organization must publicize its outcomes via program advertisement, newspaper and journal articles, conferences, or workshops (Allen \& Cooper, 2003).

Thus, recreation professionals in afterschool programs as well as other settings can promote youth development, in part, by intentionally designing programs that promote protective factors that use the concepts of resiliency (Ellis, et al., 2001).

\section{Hypotheses}

$\mathrm{H}_{1}$ : Compared to pre-test scores on the RASP, post-test scores for the treatment group will be significantly higher following the after-school program.

$\mathrm{H}_{2}$ : There will be fewer discipline referrals during and after the program. 


\section{Methods}

Development of the afterschool program in this study was informed by the RALLY afterschool program (Johnston, 2009), a review of the resiliency literature (Wolin \&Wolin, 1993) and literature on the benefits of afterschool programming (e.g., Witt, 2005), and positive youth development (Cheon, 2008). The afterschool program, League 56 Academy, was identified as the experimental treatment and the elementary students chose whether or not they attended (drop-in program).

This study utilized a quasi-experimental, nonequivalent control group design to assess the effect of the afterschool program on $5^{\text {th }}$ and $6^{\text {th }}$ graders' resilience. In addition, an effort was made to track instances of negative behavior in $5^{\text {th }}$ and $6^{\text {th }}$ graders prior to, during, and following the afterschool program.

\section{Sample}

The principal of an elementary school in Central New York (CNY) asked the faculty at SUNY Cortland to help with Recreation Time (formally known as Recess Time) to assist in intentional programming with the hopes to decrease occurrences of bullying. The problem was occurring primarily between the $5^{\text {th }}$ and $6^{\text {th }}$ grade students. The program was open to all $5^{\text {th }}$ and $6^{\text {th }}$ graders, which included about 120 students.

\section{Measurement}

The seven resiliency traits identified and described by Wolin and Wolin (1993) served as the theoretical foundation upon which the League 56 Academy was developed. The seven traits were operationalized via the Resiliency Attitudes and Skills Profile (RASP), which consisted of a series of 40 "I - statements" with multiple inquiries about each of the seven resiliency traits. Items were measured on a 6 - point, Likert-type scale, with 1 = Strongly Disagree and $6=$ Strongly Agree (Hurtes, 1999).

The RASP has a reported internal consistency of .91 (Hurtes \& Allen, 2001). Although the RASP specifically measures the seven constructs separately, the assessment shows higher levels of internal consistency for the test as a whole (Hurtes \& Allen, 2001). Hurtes and Allen reported that the RASP is also positively correlated with the Psychological Well-Being scale $(r=.47)$ and negatively correlated with the Psychological Distress scale $(r=-0.22)$.

Aggressive behavior or bullying was measured using the number of behavioral referrals or "pink slips" students received. Referrals were reported to the principal by teachers and school aides during school hours. Thus, the definition of "bullying" was left up to the supervising administrators within the school.

\section{Design}

In an effort to build a sense of community within the school, the $5^{\text {th }}$ and $6^{\text {th }}$ grade cohort was referred to as "League 56." In the fall of 2009, students were introduced to the afterschool program known as "League 56 Academy." League 56 Academy occurred twice weekly for eight weeks. Each week one of the seven resiliency traits was targeted through intentional programmed recreation activities. During the last week, a summary of resiliency was the focus. All recreation activities were cooperative-based, teambuilding exercises rather than competitivebased experiences. 
League 56 Academy was programmed and facilitated by undergraduate students majoring in Recreation, Parks and Leisure Studies at SUNY Cortland. These students were enrolled in recreation programming and leadership courses. Integrated into the curriculum of these two courses were program design and facilitation techniques specific to the League 56 Academy. Students developed a "Weekly Activity Plan" (WAP) describing activities relevant to the resiliency trait of the week, and including a measurable objective for the target trait. WAPs typically included a series of six thematically related recreation activities with detailed instructions on how to implement each activity. Students also practiced facilitating the designated activities prior to the start of the League 56 Academy.

The program followed the same schedule each day it was offered. For the first 30 minutes, the SUNY Cortland students provided homework assistance to the $5^{\text {th }}$ and $6^{\text {th }}$ graders. This was followed by a healthy snack provided through a USDA grant for afterschool programs. Elementary students then checked in with their group leaders and participated in a high energy, large group activity designed to get them moving and ready for the afternoon. Students were then split into smaller groups [on average eight] where they participated in the activities intentionally designed to target the resiliency trait for that week. Specific activities were selected to promote the trait of the week. For example, during the week of Relationships, the following activities were some of the selections. 1) Trust walk/run to encourage trusting classmates during the activity. This activity foster the idea of building trust among classmates and rather than testing it. 2) Communalities [sic] is an activity that explores similar interests among the students. For example, through the activity students learn such things as what they enjoying doing in free time, or what they would like to do when they grow up. 3) Key Punch is a challenge activity that allows for groups to have leaders, and followers to accomplish a task within a given timeframe. This activity also promotes planning and problem-solving within a group, require students to listen to one another and follow through with handling conflicts. Following the activities, students engaged in a reflective learning session utilizing open-ended questions, tangible objects, and other resources to help them process their experience. The following table illustrates a typical day in the program. 
Table 1

Example Program Schedule

\begin{tabular}{|c|c|c|}
\hline Time & Activity & Description \\
\hline $\begin{array}{l}2: 50-3: 05 \\
(15 \text { minutes })\end{array}$ & $\begin{array}{l}\text { Program Preparation \& } \\
\text { Set-up }\end{array}$ & $\begin{array}{l}\text { Leaders will set up any needed supplies and props for that day's } \\
\text { program, either outside or in the gym (weather dependent). }\end{array}$ \\
\hline $\begin{array}{l}3: 05-3: 15 \\
(10 \text { minutes })\end{array}$ & $\begin{array}{l}\text { Attendance and Snack } \\
\text { Check Planners }\end{array}$ & $\begin{array}{l}\text { Students will check-in with their group leaders and have the } \\
\text { option of bringing their own or being given a healthy snack } \\
\text { provided to them by the school district. } \\
\text { While the students are snacking, leaders will check the students' } \\
\text { planners to make sure they have recorded what to do for } \\
\text { homework, have the right books and papers, etc. }\end{array}$ \\
\hline $\begin{array}{l}3: 15-3: 20 \\
\text { (5 minutes) }\end{array}$ & Deinhibitizer/Icebreaker & $\begin{array}{l}\text { Students will be organized into a large group and participate in } \\
\text { an activity designed to get them moving and ready for the } \\
\text { afternoon. }\end{array}$ \\
\hline $\begin{array}{c}3: 20-3: 55 \\
\text { (35 minutes) }\end{array}$ & $\begin{array}{l}\text { Resiliency-Focused } \\
\text { Activity }\end{array}$ & $\begin{array}{l}\text { Students will be separated into groups with approximately seven } \\
\text { peers and three group leaders. Leaders will facilitate } \\
\text { intentionally structured activities in order to promote the } \\
\text { resiliency trait of that week. }\end{array}$ \\
\hline $\begin{array}{l}3: 55-4: 05 \\
(10 \text { minutes })\end{array}$ & Reflective Learning & $\begin{array}{l}\text { Following the activities, leaders will facilitate small group } \\
\text { discussions designed to help students process their experiences. } \\
\text { We will use open-ended questions, tangible objects and writing } \\
\text { materials to make this process engaging. }\end{array}$ \\
\hline $\begin{array}{l}4: 05-4: 30 \\
(25 \text { minutes })\end{array}$ & Academic Time & $\begin{array}{l}\text { Students will have the option of working on that night's } \\
\text { homework assignment, asking for help with a difficult school } \\
\text { subject or completing an assignment provided to them by us } \\
\text { (they always have homework, check Planners). }\end{array}$ \\
\hline $4: 30$ & Dismissal & $\begin{array}{l}\text { Students will pack their belongings and depart the school. } \\
\text { Group leaders and/or program coordinators will stay with the } \\
\text { children until all the children have left. }\end{array}$ \\
\hline
\end{tabular}

\section{Data Collection}

All $5^{\text {th }}$ and $6^{\text {th }}$ grade students were asked to complete the RASP before the start of the afterschool program and one-week after completion of the program. The survey administrator, who was the students' respective teacher, asked the students to complete the questionnaire honestly and to the best of their ability. It was explained to the students that their participation was voluntary and if they chose not to participate that they could simply return the sheet to the envelope after the survey had begun. The envelopes were then sealed and returned to the researchers.

\section{Data Analysis \& Results}

SPSS Version 17.0 was used to analyze data obtained from the RASP. A descriptive analysis of aggressive behavior (bullying) was performed on the number of discipline referrals reported for the $5^{\text {th }}$ and $6^{\text {th }}$ graders six weeks prior to the implementation of the program, eight weeks during the program, and five weeks following the program. Due to potential interactions that may have occurred between program participants and non-participants, rather than assessing the number of referrals assigned to participants or non-participants, a more appropriate assessment was to consider referrals for the total $5^{\text {th }}$ and $6^{\text {th }}$ grade student population. 


\section{Description of Sample}

The League 56 Academy was available and accessible to the entire $5^{\text {th }}(\mathrm{N}=69)$ and $6^{\text {th }}$ grade $(\mathrm{N}=60)$ student population at the elementary school. Of the 129 potential participants, 79 consented to participate in the study, resulting in a $61 \%$ response rate. Average attendance was eight in each of the seven small groups. Overall, an average of 32 students attended each session.

\section{Resiliency Attitudes and Skills Profile (RASP): Mean Scores of Participants and Non-} Participants

Of the 79 students selected to participate in the study, 32 of the pre and post test scores were able to be matched. Participation in the program was measured by attending eight sessions, one more than half of the meetings offered. Thirteen of the 32 matched sets met the standard to be classified as "participants" in the League 56 Academy (attended eight or more sessions) and six study participants who attended the afterschool program less than eight times were labeled "non-participants." The remaining 13 matched data sets were unable to be identified as participants or non-participants and were consequently removed from the analysis. Paired samples $t$-tests were used to compare participant/non-participant pretest and posttest scores. Change scores between groups were also assessed.

Results indicated a significant difference between participants' pretest $(M=4.349, S D=0.85)$ and posttest scores $(M=4.518, S D=0.90)$, with $t(12)=-0.745, p=.04$ with a corresponding effect size, $r_{\mathrm{pb}}^{2}=0.044$. No significant difference was found between pretest $(M=4.146, S D=$ $0.506)$ and posttest $(M=4.265, S D=0.547)$ scores for non-participants. When examining the gain scores (means of pretest minus posttest for each group), the difference was not significant (see Table 2).

Table 2

RASP - 40 Item Scale Results

\begin{tabular}{|c|c|c|c|c|c|c|c|}
\hline \multicolumn{2}{|c|}{ Groups } & $N$ & $D f$ & $M$ & $S D$ & $T$ & Sig. \\
\hline Participant & Pretest & 13 & & 4.35 & 0.854 & & \\
\hline & Posttest & 13 & & 4.52 & 0.897 & & \\
\hline & Difference & & 17 & -0.17 & -0.043 & -0.745 & $0.045^{*}$ \\
\hline Non- Participant & Pretest & 6 & & 4.15 & 0.506 & & \\
\hline & Posttest & 6 & & 4.27 & 0.547 & & \\
\hline & Difference & & 17 & -0.12 & -0.041 & -0.504 & 0.441 \\
\hline Gain Scores & Difference & 19 & 17 & 0.05 & & 0.133 & 0.606 \\
\hline
\end{tabular}

\section{Descriptive Analysis of Aggressive Behaviors}

No behavioral referrals ("pink slips") were reported for the duration of the fall semester for $5^{\text {th }}$ graders. Before the program was instituted, (month of September 2009, 17 school days) there were zero aggressive behaviors reported for $6^{\text {th }}$ grade students. During the 8 -week program (October through November 2009, 36 school days) there were five behavioral referrals (all males) submitted to the faculty. For the month of December, (17 days) there were five referrals (one female, and four males). 
Table 3

Instances of Aggressive Behaviors as reported by the Principal

\begin{tabular}{|l|l|c|c|c|}
\hline Program & Month & $\begin{array}{c}\text { School } \\
\text { Days }\end{array}$ & $\begin{array}{c}\text { Number of } \\
\text { Aggressive } \\
\text { Behaviors }\end{array}$ & $\begin{array}{c}\text { Percentage of } \\
\text { Aggressive } \\
\text { Behaviors* }\end{array}$ \\
\hline Before & September & 17 & 0 & $0 \%$ \\
\hline During & October \& November & 36 & 5 & $13.89 \%$ \\
\hline After & December & 17 & 5 & $29.41 \%$ \\
\hline$*$ Measured by: School Days/Number of Aggressive Behaviors \\
\hline
\end{tabular}

\section{Discussion}

This study used a quasi-experimental design to examine the effects of a resiliency-based afterschool program on youth. In accordance with the four-step, Benefits-Based Programming model (Allen, et. al, 1998), stakeholders, including participants, parents, school board, school administrators and teachers, were taken into consideration when creating outcome oriented program goals. The sample was hand-selected $\left(5^{\text {th }}\right.$ and $6^{\text {th }}$ graders at a local elementary school in Central New York, ) in order to address aggressive behaviors within that population.

\section{Limitations}

While an overall focus and use of resiliency seems to be a potential intervention to meet the needs of youth, it is important to note that it takes ample time and effort to combine a number of organizations, individuals, and teaching concepts to accurately tailor a program that benefits a particular population and enhances their general well-being. This was the first year the program was offered and while the sample is small the data suggest a positive trend toward increasing resilience.

Data collection and coding proved to be problematic. One of the primary concerns involved the matching of the "last four digits" of the elementary student's phone number. This was difficult for a number of reasons, e.g., phone numbers changed in the course of the semester, students forgot their number from pre to post test, some had multiple phone numbers (e.g., one for mother, one for father, or cellular versus home phone), and some students (e.g., siblings) may have had the same last four numbers (making it difficult to distinguish one set from the other). It is within these limitations that we provide a summary of findings.

\section{Summary of Findings}

\section{Research Hypothesis 1}

Accepted: Given the results of the paired samples $t$ test, participants had a significant increase in scores over non-participants.

\section{Research Hypothesis 2}

Accepted: The program had a positive impact on aggressive behavior as evidence by five referrals during the 36 days of the program, then $112 \%$ increase of referrals after the program was discontinued the 17 days before the semester ended. 


\section{Future Recommendations}

It is recommended to encourage an in-school portion so students may be introduced to the concepts that they will be encountering afterschool. In relation to those participants who did not score well within certain traits, it would be advised to assess whether an individual consistently scored poorly of if it was solely within a specific traits. It is also recommended that the teachers stress the trait of the week during school (e.g., language arts). In addition, in order to increase response rates for qualitative feedback regarding students' academic performance, it is suggested that the researcher conduct an interview or focus group with the teachers, post program.

An extension of the program is highly recommended. With a significant increase of referrals after the program ended suggest students need the program to cover the length of their school calendar, not the college calendar. One suggestion would be to adopt a year around afterschool program that models the League 56 Academy. The facilitators of this program were college students completing service-learning for class credit, this limited their interaction time. Schools seeking to have a program that extends beyond the college calendar could seek funding to hire staff (e.g., college students or other qualified youth leaders) to direct the program. Designing a program around the public school calendar would also strengthen the resiliency lessons throughout the program. Finally, ending the program at 4:30pm in the afternoon may be too short of a timeframe to effectively promote the resiliency trait of the week. Other successful programs, such as the in- and afterschool program CARE NOW, which operates as a public school/university partnership, had better results with a 10-week long program ending at 5:45pm (Hill \& Milliken, 2012).

With respect to the RASP as a measure of resiliency, most of the items used to measure resiliency held up to the various iterations of reliability and validity analyses. However, because in some cases, stark differences were found between this study's findings, in relation to Collins' (2009) and Johnston's (2009) studies, replication of the RASP on the same and other populations should continue. In addition, better attempts to match pre- and posttest data sets should be made. Although using the last four digits of phone numbers worked for many of the participants, it was problematic for others. Using a school identification or lunch number may be more effective. Furthermore, applying more rigorous analyses to the RASP would substantiate its use in afterschool, resiliency-based programs on a national level.

\section{Practical Implications and Conclusion}

Similar to previous findings (e.g., Collins, 2009), the use of recreational activities with youth can be effective at enhancing such assets as resiliency. Additionally, as mentioned before, the League 56 Academy served an average of 32 students per afterschool session. These students who were not being served afterschool prior to this program; it gave them academic assistance, positive mentors, a healthy snack, and provided them with an opportunity to develop positive outlooks on life (i.e., resiliency). Thus, the League 56 Academy using a benefits-based approach to programming to promote positive youth development may be a worthy model to replicate.

Benefits-based programming (BBP) provides practitioners a framework for engineering recreation experiences. Historically, recreation [especially afterschool] programs have often been viewed as diversionary (Allen, Stevens, Hurtes, \& Harwell, 1998). More recently, afterschool programmers have explored the impact of intentional recreation programming utilizing a BBP framework (Brown \& Hill, 2011; Hill, Brown \& Cosnett, 2011; Hill \& Milliken, 2012; Hill, Milliken \& Gómez, 2011). These and other studies further demonstrate the value of using the BBP model in identifying needs; enhancing evaluation techniques; better articulating 
the evidence-based research to the public; and further substantiating the need for funding for afterschool programs.

\section{References}

Afterschool Alliance. (2004). America after 3 p.m. Retrieved June 29, 2009, from http://www.afterschoolalliance.org/states_docs/pdfs/New\%20York\%20Fact\%20Sheet\%202008. pdf

Allen, L.R., \& Cooper, N.L. (2003). Benefits-based programming curriculum manual. Ashburn, $\mathrm{VA}$ : National recreation and park association.

Allen, L.R., Stevens, B., Hurtes, K., \& Harwell, R. (1998). Benefits-based programming of recreation services: Training manual. Ashburn, VA: National recreation and park association.

Beaty, L.A., \& Alexeyev, E.B. (2008). The problem of school bullies: What the research tells us. Adolescence, 43(169), 1-11.

Benard, B. (2004). Resiliency: What we have learned.San Francisco, CA. West Ed. Publishers.

Borden, L.M., Perkins, D.F., Villarruel, F.A., \& Stone, M.R. (2005). To participate or not to participate: That is the question. New Directions for Youth Development, 105, 33-49.

Brennan, M.A. (2008). Conceptualizing resiliency: An interactional perspective for community and youth development. Child Care in Practice, 14(1), 55-64.

Brown, L., \& Hill, E. (2011). Promoting Resiliency Among Youth: A Benefits-based Afterschool Program. $2^{\text {nd }}$ Annual Youth Development Institute, Austin, TX.

Cheon, J.W. (2008). Best practices in community-based prevention for youth substance reduction: towards strengths-based positive development policy. Journal of Community Psychology, 36(6), 761-779.

Collins, T. (2009). Design, development, and implementation of a resiliency-based afterschool program for sixth grade students through recreational activities.Unpublished Thesis.Old Dominion University, Norfolk, VA.

Cummings, M. (1999). Experiential activities specializing in anti-bullying. Pinnacle Kit Field Guide. Littleton, CO: Training Wheels.

Ellis, E.M., Braff, E., \& Hutchinson, S.L. (2001). Youth recreation and resiliency: Putting theory into practice in fairfax county. Therapeutic Recreation Journal, 35(4), 307-317.

Gottfredson, D.C., Cross, A., \& Soule, D.A. (2007). Distinguishing characteristics of effective and ineffective afterschool programs to prevent delinquency and victimization. Criminology \& Public Policy, 6(2), 289-318.

Graham, S., \& Bellmore, A.D. (2007). Peer victimization and mental health during early adolescence. Theory into Practice, 46(2), 138-146. 
Hill, E., Brown, L., \& Cosnett, E. (2011). Creating a benefits-based afterschool program. The Voice, Winter, 16-18.

Hill, E., \& Milliken, T. (2012). Benefits based programming: A collaborative model serving diverse populations. National Recreation and Park Association Congress and Exposition, Anaheim, CA.

Hill, E., Milliken, T., \& Gomez. (2011). In and Afterschool Programming: A Benefits-based Model. $57^{\text {th }}$ Virginia Recreation and Park Society Annual Conference, Norfolk, VA.

Hurtes, K.P., \& Allen, L.R. (2001). Measuring resiliency in youth: The resiliency attitudes and skills profile. Therapeutic Recreation Journal, 35(4), 333-347.

Hurtes, K.P., Allen, L.R., Stevens, B.W., \& Lee, C. (2000). Benefits-based programming: Making an impact on youth at-risk. Journal of Park and Recreation Administration,18(1), 34-49.

Johnston, A. (2009). Afterschool programs: Resiliency through recreation. Unpublished Thesis. Old Dominion University, Norfolk, VA.

Kelley, T.M. (2003). Health realization: A principle-based psychology of positive youth development. Child \& Youth Care Forum, 32(1), 47-71.

Lerner, R., Lerner, J., Almerigi, J., \& Theokas, C. (2005). Positive youth development: A view of the issues. Journal of Early Adolescence, 25(1), 10-16.

Roffman, J.G., Pagano, M.E., \& Hirsch B. J. (2001). Youth functioning and experiences in innercity after-school programs among age, gender, and race group. Journal of Child and Family Studies, 10(1), 85-100.

Witt, P.A. (2005). Widespread support for the development of afterschool programs. In P.A. Witt \& L.L. Caldwell (Eds.), Recreation and youth development (pp. 301-327). State College, PA: Venture Publishing, Inc.

Witt, P. (2002). Youth development: Going to the next level. Parks \& Recreation, 373), 52-29.

Wolin, J., \& Wolin, S. (1993). The resilient self: How survivors of troubled families rise above adversity. New York: Villard books.

(C) Copyright of Journal of Youth Development Bridging Research and Practice. Content may not be copied or emailed to multiple sites or posted to a listserv without copyright holder's express written permission. Contact Editor at: patricia.dawson@oregonstate.edu for details. However, users may print, download or email articles for individual use.

ISSN 2325-4009 (Print); ISSN 2325-4017 (Online) 